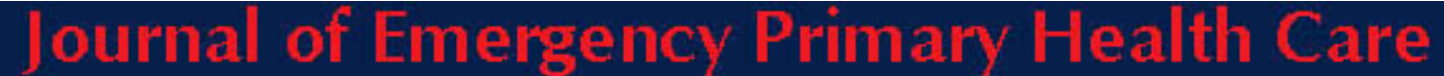

An International elournal of Prehospital Care Research, Education, clinical Practice, Policy and Service Delivery

ISSN 1447-4999

\title{
POLICY AND SERVICE DELIVERY
}

Article No. 190195

\section{National Disaster Preparedness in Australia - Before and After 9/11}

\author{
Erin Smith \\ Research Fellow, Centre for Ambulance and Paramedic Studies \\ Monash University, Melbourne, Australia.
}

\section{Introduction}

Throughout history, certain major events or disasters have served as "focusing events", leading to the development of new legislation, policy, planning, and practices. ${ }^{1,2}$ While many of these events have led to significant changes in terms of planning, preparedness, and consequence management (of particular note are the changes to preparedness and response in Israel and the Middle East following warfare and conflict), one event was the ultimate "focusing-event", with no other event bringing about changes of a comparable scope or scale. ${ }^{3}$

On the $11^{\text {th }}$ of September, 2001, the world watched as four hijacked commercial airliners were crashed into the World Trade Centre Buildings in New York City, the Pentagon in Washington DC, and a rural field in Pennsylvania. The attacks resulted in the deaths of an estimated 3124 people, ${ }^{4} 409$ of whom were emergency service personnel. $^{5}$ The events that occurred that day resulted in unprecedented changes to public health and disaster preparedness systems, not only in the US, but worldwide.

The International Federation of Red Cross and Red Crescent Societies (IFRC) define disaster preparedness as "measures taken to prepare for, and reduce the effects of disasters". 6 This definition further states that disaster preparedness is designed to predict - and where possible - prevent disasters, mitigate their impact on vulnerable populations, and respond to and effectively cope with their consequences. Furthermore, giving due acknowledgement to the broad disciplinary basis of the field, disaster preparedness should be viewed as a "goal" rather than a specialised program or distinct "activity". ${ }^{6}$

The IFRC suggest that disaster preparedness should be a continuous and integrated process resulting from a wide range of contributors, resources and activities. From the IFRC perspective, disaster preparedness has the following objectives:

1. Increasing the efficiency, effectiveness and impact of disaster emergency response mechanisms at the community and national level. 
Journal of Emergency Primary Health Care (JEPHC), Vol.4, Issue 2, 2006

2. Strengthening community-based disaster preparedness through national programmes for the community, and through direct support of the communities own activities.

3. Developing activities that are useful for addressing both everyday risks that the community may face, as well as responding to disaster situations.

With this definition in mind, this paper will examine how the field of disaster preparedness has developed in Australia at a national level, using the ultimate focusing event of 9/11 as a marker for change.

\section{National Disaster Preparedness Before 9/11}

Disaster preparedness in Australia has been moulded by a number of historical influences; ${ }^{7}$

1. A heritage born out of civil defence and military traditions.

2. A focus on natural hazards.

3. Focusing on response rather than preparedness and prevention.

4. A strong reliance on volunteerism.

In the early 1900's, the Australian approach to disasters was focused on response, with the most visible "disaster management" agency being the Red Cross. The Australian Red Cross provided assistance after World War I in response to the 1918 "Spanish Flu" influenza epidemic reaching Australia shores. Following World War II, the Western Australian Division of the Australian Red Cross Society was the first State to move strongly into civil preparedness for disaster, ${ }^{8}$ giving special emphasis to disaster preparedness as part of the larger role of the Red Cross in caring for victims of natural disasters, conflict and human tragedies. State divisions of the Australian Red Cross would respond by taking on the concept of disaster preparedness, and by the 1960's, Red Cross divisions throughout the country had become affiliated with state-based emergency and disaster services, and were focusing on disaster "preparedness" in addition to "response".

Throughout the 1960's and 1970's, natural hazards were still the greatest disaster threat to Australian communities (such as the Tasmanian bushfires of 1967). In recognition of this threat, the Natural Disasters Organisation (NDO) was established in 1974, within the Department of Defence. In light of the greater number and wider variety of potential threats confronting society, it became evident that disaster management had to move beyond focusing on response, to investigating methods for prevention and mitigation. In response, the NDO expanded the scope of existing Commonwealth civil defence capabilities to include preparedness for natural disasters.

Following shortly after the development of the NDO, the Australian Red Cross Society formed a National Disaster Relief Committee, and the Red Cross Disaster Services Department was formed in 1975. At a national level, the Red Cross National Officers implemented uniform patterns of organisation and training throughout Australian Red 
Cross divisions and became increasingly involved in disaster preparedness initiatives, including education and first aid training. These developments would be tested during the 1970's and 1980's when two major disasters required national collaboration in response efforts, and further emphasised the need for disaster preparedness initiatives.

Cyclone Tracy devastated Darwin on Christmas Eve, 1974. One of the worst natural disasters in Australian history, Cyclone Tracy substantially destroyed Darwin and killed 65 people. Earlier in that December in 1974, Cyclone Selma had approached Darwin before changing course and disappearing back over the ocean. It is reported by the Northern Territory Government archives that there was a widespread relief that Tracy would behave similarly. While Darwin residents for the most part went about celebrating Christmas, many individuals, businesses, and government departments prepared for the threat of Tracy. Had these basic preparedness activities (such as evacuating homes and seeking shelter), not been undertaken, the death and destruction inflicted by Tracy would have been much higher. ${ }^{9}$ Indeed, it was both the actions, and inactions, in the lead up to, and in the wake of Tracy that shaped much of Australia's preparedness for Cyclones today (most notably the introduction of structural requirements for buildings in cyclone prone areas).

Not quite 10 years later, on the $16^{\text {th }}$ of February 1983 - "Ash Wednesday”, over 100 bushfires swept through Victoria and South Australia, killing 75 people and causing widespread destruction and damage. Australia's natural environments are some of the most fire-prone areas in the world. High temperatures and limited summer rainfall produces conditions of very high fire danger in Australia's large eucalypt forests. Sudden strong wind changes, which can cause fires to become uncontrollable, are also common. ${ }^{10}$ Leading up to Ash Wednesday the majority of Victoria had experienced a drought which had lasted 10 months or more. The Victorian Department of Sustainability and Environment reports that there had been little rain fall during the previous winter and spring, resulting in ample fuel for bushfires in the form of dry leaves, twigs and other vegetation.

In perhaps one of the first "disaster preparedness" initiatives in the country, the hot dry lead up to the 1983 summer gave firefighters and public health planners an early warning of what might lie ahead. Indeed, the first "Total Fire Ban” day ever declared occurred in the lead up to Ash Wednesday, on November 24, 1982. Victorian Government firefighting agencies employed extra staff and organised for additional equipment and aircraft to be ready for firefighting over summer. This was followed over the years with numerous print and electronic media campaigns on how to prepare for bushfires, including advice on how to prepare your home, developing emergency kits and evacuation plans, and the development of local emergency hotline numbers where advice could be sort in the event of a bushfire. Bushfire preparedness initiatives were aimed at all ages, with primary and secondary school students learning to "Get down low, and go, go, go".

Following Cyclone Tracy and Ash Wednesday, a group, focusing specifically on disaster preparedness, was developed under the umbrella of Red Cross agencies. An 
expert committee comprising national Red Cross members was formed to specifically address the issue of disaster preparedness, and to advise, coordinate, and support the development of disaster preparedness services.

During the 1990's, a shift occurred at the National disaster preparedness level, with the NDO renamed Emergency Management Australia (EMA) in 1993, and the development of the National Emergency Management Committee. The mission of EMA was set as providing national leadership in the development of measures to reduce risk to communities and to manage the consequences of disasters. On the $19^{\text {th }}$ of June, 1993, EMA sponsored one of its first projects, in collaboration with the Centre for International Research on Communication and Information Technologies (CIRCIT). The Australian Disaster Management Information Network (ADMIN) was developed in 1993 by national and state wide governments to enhance the effectiveness of disaster management and disaster preparedness through the improved coordination and availability of information.

In response to ongoing demand for emergency and disaster preparedness and mitigation, the National Emergency Management Committee endorsed the development of a national disaster mitigation strategy on the $25^{\text {th }}$ September, 1996. A subsequent Disaster Mitigation workshop conducted in April 1997. This workshop resulted in the formation of a Mitigation Working Group, who held their inaugural meeting in July 1998. In collaboration with Emergency Management Australia (EMA), mitigation measures were developed for several hazards; flood, earthquake, cyclones and severe storms, and bushfires. The focus on these hazards was reflective of the perceived major disaster threats in Australia - particularly bushfires, floods and extreme weather.

As urbanisation and industrialisation continued to increase throughout Australia, the threats to society began to change. Historically, most hazards to Australian communities had been "natural" (including the 1918 influenza pandemic, as well as bushfires and floods), however, over the years more "man-made" hazards and events began to evolve. One such man-made disaster, the Longford gas explosion in Victoria, reinforced the need for preparedness and prevention, not just response. On Friday 25 September, 1998 an explosion and fire at the Longford gas plant killed two men and injured eight workers. The explosion resulted in the cessation of gas supply for two weeks in the state of Victoria, resulting in unprecedented economic losses for Victorian businesses (in particular the hospitality industry that relied on gas for cooking), with damage to the economy estimated at $\$ 1.3$ billion. ${ }^{11}$ Gas supply was not re-instated in Victoria until the $14^{\text {th }}$ October, 20 days after the explosion.

In June 2001, the Council of Australian Governments (COAG) commissioned a review of Australia's approach to natural disasters. The final report, ${ }^{12}$ released in February 2004, Natural Disasters in Australia: Reforming Mitigation, Relief and Recovery Arrangements, concluded that current disaster management approaches would benefit from broadening the focus of then current initiatives - response and reaction - to placing a greater emphasis on preparedness and mitigation. Furthermore, the report recommended a unified national approach with an emphasis on mitigation. 
These activities, while somewhat limited in scope, prove that Australia was investing time and resources into preparing for disasters prior to September 11. Specifically, the Australian Government was reviewing the capability of the nation to prevent, respond, and recover from our perceived greatest disaster threat - natural disasters. The National Government was also investigating how to best utilise existing state-wide and local resources and agencies, and how to best incorporate the Department of Defence into disaster responses. While the National Government has responsibility for military defence, the responsibility for civil defence is held jointly by the National Government and State Governments, with a recognised need for co-operation and co-ordination throughout the Country. ${ }^{13}$

Consequently, the majority of Australia's disaster preparedness planning prior to September 11 was focused on preparing for bushfires and dealing with the effects of extreme weather, particularly cyclones.

\section{National Disaster Preparedness Following 9/11}

Disaster preparedness became a priority across national and state-wide Governments, as well as at the local Council level following September 11. In November 2001, Emergency Management Australia (EMA) was moved from Defence to the AttorneyGeneral's Department, reflecting a change in the responsibilities and duties of the organisation. With a greater focus on consequence management, EMA was identified as Australia's lead agency for the coordination of Australian Government assistance in managing disasters in Australia.

Emergency Management Australia (EMA) developed 4 Australian Government Disaster Response Plans, all of which would be called upon in the following years, perhaps most notably in response to the Bali bombings;

1. Commonwealth Government Disaster Response Plan (COMDISPLAN)

This plan coordinates the provision of Australian Government physical assistance in the event of a disaster in Australia or its offshore Territories.

2. Commonwealth Government Overseas Disaster Assistance Plan (AUSASSISTPLAN)

This plan coordinates the provision of Australian emergency assistance, using Australian Government physical and technical resources, following a disaster in another country.

3. Australian Contingency Plan for Space Re-entry Debris (AUSCONPLAN SPRED)

This plan coordinates and controls the activities of Commonwealth agencies in support of State/Territory authorities involved in locating, recovering and removing radioactive space debris, and monitoring and 
Journal of Emergency Primary Health Care (JEPHC), Vol.4, Issue 2, 2006

neutralising any radiological contamination threat arising from re-entry of radioactive space debris.

4. Commonwealth Government Reception Plan (COMRECEPLAN)This plan coordinates the reception of persons evacuated into Australia following an overseas event.

Following September 11, EMA was formally included as a member of the National Counter-Terrorism Committee (NCTC). The NCTC recognised the need to improve the ability of emergency service providers to respond to an incident involving chemical, biological and radiological (CBR) hazards. In the 2002- 2003 Budget, the Australian Government committed $\$ 17.8$ million to improving the CBR response capabilities of States and Territories. A National CBR programme was developed to ensure a standardised and cooperative approach throughout Australia. EMA procured and delivered equipment for detection, personal protection and CBR support to all states and territories, and provided training to those emergency services personnel likely to be first on the scene after an incident. Delivery of equipment for decontamination, casualty extraction and casualty management commenced to Australian hospitals mid-2004. ${ }^{14}$

Disaster plans throughout the Country were reviewed and updated post September 11, with further comprehensive review conducted after our experience with the Bali bombings, October 2002. At approximately $11 \mathrm{pm}$ on the $12^{\text {th }}$ of October, two bombs were detonated in a busy nightclub and entertainment region of Bali. The bombings resulted in 202 deaths and 209 injuries. The largest international group among the killed and injured were Australian's on holiday. The Bali bombings provided a unique opportunity for Australia to review its disaster preparedness and response capabilities, with the evacuation and treatment of 86 injured people to 17 hospitals in six states and territories. ${ }^{14}$

The National Medicines Stockpile was established in Australia in 2002 to ensure an adequate supply of pharmaceuticals and equipment in response to a disaster. The National Medicines Stockpile was augmented in the lead up to the Sydney 2000 Olympic Games, and since July 2002, the Australian Government has committed an additional \$27 million to upgrade Australia's national medicines stockpile. The Stockpile has been designed to supplement existing medical stock held by Australian hospitals. The stockpile includes a range of vaccines, antibiotics, chemical antidotes and diagnostic tests. ${ }^{14}$

The threat of Severe Acute Respiratory Syndrome (SARS) in 2003 further reformed disaster planning, placing an emphasis on planning and preparing Australia for healthrelated disasters. The Australian Health Disaster Management Policy Committee (AHD-MPC) was established by the Australian Health Ministers' Advisory Council in February 2003, and has since been renamed the Australian Health Protection Committee (AHPC). The Committee was established to identify Australia's level of preparedness to respond to the consequences of a terrorist attack or a naturally occurring disaster, and 
to coordinate the national response in the event of a health-related disaster. Committee members include a senior health official from each Australian State and Territory, in addition to experts in public health, mental health, clinical and emergency care. The Australian Defence Force, Emergency Management Australia and a senior health officer from New Zealand are also members of the new Committee.

Australia's ability to assist in the response to major disasters was tested when international medical assistance was sought following the Indian Ocean Tsunami on December 26, 2004. Australia's role in responding to that disaster lasted well into 2005, with ongoing assistance being provided by both National and State-wide Governments. Following the tsunami, the Australian Government committed funding of \$68.9 million over four years in the 2005-2006 Federal Budget to enhance the Australian Tsunami Alert System (ATAS) and establish the Australian Tsunami Warning System (ATWS).

Implemented by EMA, Geoscience Australia (GA), and the Bureau of Meteorology (Bureau), the ATWS is a part of a planned network of national systems to form the Indian Ocean Tsunami Warning System (IOTWS), and adds to the current capability of the Pacific Tsunami Warning System (PTWS) in the south-west Pacific. Significant progress in implementing various elements of the ATWS, such as the upgrade of each agency's operations centre to address the tsunami risk, has been made. From a community engagement perspective, EMA is working with States and Territories and relevant industry, education, volunteer and community sectors to enhance community preparedness through awareness raising, education and training. This will be achieved through a whole-of-government, all hazards approach to assessing current and future emergency management arrangements for communities. ${ }^{15}$

Most recently, the attention of disaster planners and emergency managers world-wide has turned to the threat of an Avian Influenza Pandemic. In Australia, the main focus of disaster planning in 2005 was the redevelopment of the Australian Pandemic Influenza Action Plan. While developed at a Federal level, this plan was developed in consultation with State and Territory Governments, Commonwealth agencies, and health experts. ${ }^{16}$ In response to the Influenza threat, the National Medicines Stockpile has \$123.8 million allocated for anti-viral medicine to prevent and treat pandemic influenza introduced by natural or deliberate means. ${ }^{14}$

In May 2005, it was reported that the Australian Government would establish an independent, WHO Collaborating Centre for Reference and Research on Influenza. The 2005-2006 National Budget provided \$23.2 million over 4 years to establish the independent Centre. The Minister for Health and Ageing, Mr Tony Abbott, reported that the Centre, one of 4 worldwide, would enhance Australia's capacity to identify deadly and contagious influenza strains, such as the avian influenza, H5N1 strain. The Australian Centre will be the main source of influenza expertise in the Country, and will provide information to the WHO on influenza activity and trends in the Southern Hemisphere. $^{17}$ 
The Australian Mass Casualty Burn Disaster Plan (AusBurnPlan) was developed in response to September 11, the Bali bombings, the Madrid bombings, and the London bombings. These events highlighted the fact that many patients suffered significant burn injuries as well as other multiple system trauma, ${ }^{18}$ and identified that these types of incidents provide particular challenges to providing optimal patient care. The AusBurnPlan can activate national assistance to an affected jurisdiction by moving medical teams in and redistributing patients to other hospitals to ensure that the most appropriate care is delivered. ${ }^{19}$

The drafting of the Mass Casualty Burn Disaster Plan commenced shortly after a second terrorist attack in Bali. On October 2, 2005, 5 bombs were detonated in Bali (Jimbaran, Nusa Dua and Kuta), killing 24 people and injuring 101. While not on the same scale as the 2002 Bali bombings, this attack served as a bleak reminder to all disaster preparedness professionals in Australia that we are not immune to terrorism, and that while geographically we may be somewhat isolated from the rest of the world, terrorist events on international shores can impact on our health care services and communities.

Following this second Bali attack, an important development in the area of Disaster Preparedness in Australia was initiated. Federal funding was provided to develop the National Trauma Centre at the Royal Darwin Hospital (who provided an effective receiving and treatment point for victims of both the 2002 and 2005 Bali bombings). The Centre was developed to enhance Australia's ability to mount a prompt and effective health response to any emergency involving significant casualties in northern Australia or nearby countries. ${ }^{20}$ In addition to the establishment of the National Trauma Centre in Darwin, two specialised Chairs (a Chair of Emergency Preparedness and Response at the Northern Territory Clinical School, and a Chair of Trauma and Critical Care at the Menzies School of Health Research) will further enhance the overall response capability of Australia. ${ }^{19}$

A greater emphasis has also been placed on training and simulated events. Two noteworthy simulated events are the 2003 Royal Adelaide Hospital "Supreme Truth" exercise, the "Explorer" exercise in Sydney in 2004, and the National "Mercury '05" exercise. These large-scale exercises tested Australia's ability to respond to disasters, specifically CBR and terrorism. In 2003, exercise "Supreme Truth" evaluated a large public hospital's ability to respond during a CBR event. The exercise proved a success and resulted in changes to the South Australian Major Incident Plan, identification of infra-structure and facilities required to respond to a CBR event, and highlighted the necessity for tested inter-agency communication and co-operation. ${ }^{21}$

The 2004 "Explorer" exercise in Sydney involved a terrorist bombing scenario in the Central Business District of Sydney. A National Counter-Terrorism Committee exercise, "Explorer" was a three day exercise designed to evaluate crisis and consequence management. Using a purpose built venue, over 250 patients were triaged and treated by ambulance services and specialist health teams. As part of "Explorer" the AusBurnPlan was also tested. The Mercury '05 exercise was a national, multijurisdictional event that was designed to evaluate the management of mass casualties, 
resulting from a terrorist attack. Mercury '05 tested the response capabilities of Western Australia, New South Wales, South Australia, Victoria and the Australian Capital Territory. The findings from Mercury '05 were incorporated into Victorian planning for the 2006 Commonwealth Games in Melbourne.

In addition to these "real-time" scenarios, the number of table-top exercises being conducted around the Country continues to increase. The development of the "Emergo Train" system, a pedagogic educational simulation system developed at the Centre for Teaching and Research in Disaster Medicine and Traumatology, has allowed a greater number of Hospitals to run scenarios as the system does not require actual facilities or emergency departments to be used for the scenario. Rather, the system utilises a series of white boards which become dedicated areas of the hospital, representing patients, staff and resources. Movable magnetic markers indicate priority and treatment and allow the users to evaluate their response.

The role of the Department of Defence in disaster preparedness and response continues to broaden. Administration and operational roles have expanded to encompass response to terrorism, border security, policing actions, international rebuilding and security, and a variety of emergency management, public order and social services. This broadened scope has resulted in progressive changes to the roles and functions of the Australian Department of Defence. While the Defence Force has, and will continue to have a primary role in military activities, secondary roles such as disaster preparedness and response appear to be becoming integrated into their core business. ${ }^{22}$

Most recently, Australia's disaster preparedness was tested with Cyclone Larry. Cyclone Larry crossed the tropical north Queensland coast on the morning of March 20, 2006. Larry inflicted major damage on homes, businesses, as well as causing extensive damage to local crops. Unfortunately, many of the lessons learned from Tracy in 1974 had not been implemented in north Queensland. Furthermore, not unlike New Orleans in the US, problematic geographical issues had been identified in the region but had not been addressed. Luckily, Queensland escaped relatively unscathed, but Larry provided another reminder that Australia needs to be prepared for all hazards and disasters.

On the $9^{\text {th }}$ May, 2006, the Australian Government announced funding of $\$ 8.4$ million over four years to improve Australia's ability to respond to chemical, biological, radiological and nuclear (CBRN) incidents. The Australian Attorney-General reported that this funding reflected the ongoing need for research and development to improve Australia's capabilities to deal with terrorism. ${ }^{23}$ In addition, the Australian Government will spend \$6.0 million on research and development to support Australia's CBRN capabilities covering areas such as personal protective equipment (PPE) and clothing, decontamination, detection, mitigation and recovery. A further $\$ 2.4$ million will provide for deployable mortuary services to help manage large numbers of fatalities that might result from terrorist attacks involving CBRN weapons. The programme will be administered by Emergency Management Australia, a division of the AttorneyGeneral's Department. ${ }^{24}$ 


\section{National Disaster Preparedness in Australia, 2006}

Today, globalisation is an influential factor on disaster preparedness in Australia. While the September 11 attacks, Bali Bombings and SARS outbreak did not occur on our soil, their impact was truly felt here in terms of resulting changes to disaster preparedness priorities, planning and funding. Currently, planning and preparedness for an avian influenza (H5N1) pandemic is high on the list (if not at the top) of disaster preparedness priorities in Australia. Epidemiological modelling estimates have suggested that if an H5N1 avian influenza pandemic occurs, the worldwide mortality rate could be on the scale of the 1918 Spanish Flu epidemic that claimed between 20 and 40 million lives. ${ }^{25}$

Surveillance systems and the use of anti-viral drugs and vaccinations are hoped to reduce these "worst-case scenario" figures. However, one thing remains clear, if H5N1 does become pandemic in the human population, the SARS epidemic of 2003 will have provided a mere hint of the economic and social disruption that a new pandemic - or "health disaster" - would inflict upon the world. As Joshua Lederberg and his colleagues pointed out, microbes are the only natural predators that continue to pose a threat to our survival. ${ }^{26}$ In this light, perhaps H5N1 could prove to be natures ultimate "terrorist”, and the ultimate test to Australia's national disaster preparedness. 


\section{References:}

1. Birkland T. After Disaster: Agenda Setting, Public Policy, and Focusing Events. Washington DC: Georgetown University Press.

2. Rubin C, Renda-Tenali I. Disaster Timeline: Selected Events and Outcomes (19652000). Arlington, VA: Claire B. Rubin and Associates, 2000.

3. Tierney K. Recent Developments in U.S. Homeland Security Policies and their Implications for the Management of Extreme Events. Presented at the First International Conference on Urban Disaster Reduction, Kobe, Japan, January 2005.

4. Centres for Disease Control and Prevention. National Vital Statistics Reports. May 24, 2002;50(8):3 (Table 3) Available from: http://www.cdc.gov/nchs/data/nvsr/nvsr50/nvsr50_08.pdf Accessed May 6, 2006.

5. Asaeda G. World Trade Centre Attack. Presented at the International Congress on Disaster Medicine and Emergency Management. Yale, New Haven, September 2005.

6. International Federation of Red Cross and Red Crescent Societies (IFRC). Introduction to Disaster Preparedness - Disaster Preparedness Training Program 2000. Available from: http://www.ifrc.org/what/dp/manual/introdp.pdf Accessed June 10, 2006.

7. Emergency Management Australia (EMA): What is Emergency Management? Available from: http://www.ema.gov.au. Accessed June 8, 2006.

8. Minogue N. The More things change...The Australian Red Cross 1914-1989, Australian Red Cross Society, 1989.

9. Northern Territory Government Library: Available from: http://www.ntlib.nt.gov.au/tracy Accessed June 10, 2006.

10. Department of Sustainability and Environment, Victoria: http://www.dse.vic.gov.au.

11. Hopkins A. Lessons From Longford: The Esso Gas Plant Explosion, CCH Australia Limited, 2000. Available from: ISBN 1864684224.

12. Council of Australian Governments (COAG). Natural Disasters in Australia: Reforming Mitigation, Relief and Recovery Arrangements - A Report to the Council of Australian Governments August 2002, Released 02/02/04. Available from: http://www.data.gov.au/cca Accessed May 8, 2006.

13. Department of Defence, Australia. Defence Instructions (General): Defence Assistance to the Civil Community - Policy and Procedures. 16 March, 2004, Department of Defence, Canberra, Australia. 
14. Australian Government, Department of Prime Minister and Cabinet. Protecting Australia Against Terrorism: Australia's Response Capability. Available from: http://www.dpmc.gov.au/publications/protecting_australia/response/1_incident.htm Accessed May 7, 2006.

15. Emergency Management Australia (EMA): ATWS. Available from: http://www.ema.gov.au/agd/ema/emainternet.nsf/Page/Tsunami_Warning Accessed February 6, 2006.

16. Department of Health and Ageing, Australian Government. Australia's Health Emergency Preparedness and Response. Available from: http://www.health.gov.au/internet/wcms/publishing.nsf/Content/phd-healthemergency.htm Accessed May 7, 2006.

17. Abbot T. MHR. Media Release: “Independent Flu Centre to Protect Australian’s Against Pandemic Flu”. 10 May 2005, ABB044/05. Available from: http://www.health.gov.au/internet/budget/publishing.nsf/Content/health-budget2005hbudget-hmedia04.htm/\$FILE/hmedia04.pdf Accessed June 8, 2006.

18. Cooper D. AusBurnPlan Strategy Paper. Australian Mass Casualty Burn Disaster Plan. National Burns Planning and Coordination Committee. Final Draft. Presented at the Australian Health Ministers Conference, June 2004. Available from: http://www.health.gov.au/internet/wcms/publishing.nsf/Content/phd-healthemergency.htm/\$FILE/ausburn.pdf Accessed May 7, 2006.

19. Murnane M, Cooper D. Is the Australian Hospital System Adequately Prepared for Terrorism? The Australian Governments Response. Medical Journal of Australia 2005;183(11/12):572-573.

20. National Budget - Australia - 2005-2006, Health. Available from: http://www.health.gov.au/budget2005 Accessed May 12, 2006.

21. Edwards NA. Exercise: “Supreme Truth” - The Report. Adelaide: Mediflight, 2003.

22. Pitman G. Queensland Emergency Response Capacity: Policy Implications for the Future. Australian Journal of Emergency Management 2006;21(2):3-10.

23. Attorney-General, Phillip Ruddock. Media Report. Available from: http://www.ema.gov.au/agd/EMA/emaInternet.nsf/Page/NewsMedia Accessed June 2, 2006.

24. Emergency Management Australia (EMA): News and Media, May 9, 2006. Available from: http://www.ema.gov.au/agd/EMA/emaInternet.nsf/Page/NewsMedia Accessed June 8, 2006. 
25. Smith E, Coghlan B, Leder K. Avian Influenza: Avian Influenza: Clinical and Epidemiological Information for Paramedics and Emergency Healthcare Workers. Journal of Emergency Primary Health Care [serial on the Internet]. 2006;3(3). Available from: http://www.jephc.com/full_article.cfm?content_id=335. Accessed June 10, 2006.

26.Lederberg J, Shope RE, Oaks Jr SC (Eds). Emerging Infectious Diseases: Microbial Threats to Health in the United States. Washington DC, National Academy Press, 1992.

\section{Author Disclosure}

The author has no financial, personal or honorary affiliations with any commercial organization directly involved or discussed in this study. 